A N N A L E S

UNIVERSITATIS M A R I A E C URIE-SKŁODOW S K A

LUBLIN - POLONIA

VOL. XXXI, 4

SECTIO J

2018

Uniwersytet im. Adama Mickiewicza w Poznaniu. Wydział Nauk Społecznych

\title{
ALEKSANDRA JASIELSKA
}

ORCID: 0000-0001-7874-5086

aleksandra.jasielska@amu.edu.pl

\section{„Podróża każda miłość jest”. Akceptacja metafor miłości przez kobiety w kontekście twórczości emocjonalnej- doniesienie wstępne}

"Every Love is a Journey". Acceptance of the Metaphor of Love by Women in the Context of Emotional Creativity

\section{STRESZCZENIE}

Miłość jest uczuciem złożonym. Z jednej strony to doznanie pozytywne, z drugiej zaś jego konceptualizacja posiada elementy negatywne. Jedną z form leksykalnego rozumienia emocji jest model metaforyczny, który umożliwia dotarcie do pozadosłownego znaczenia emocji. Aby ustalić potoczne rozumienia miłości, zrealizowano badania z udziałem kobiet $(\mathrm{N}=43)$, wykorzystując typowe (nośnik i temat obdarzone tą samą walencją emocjonalną) i nietypowe (nośnik i temat obdarzone przeciwną walencją emocjonalną) metafory miłości. Zmierzono także doświadczenie aktualnego afektu oraz twórczość emocjonalną Uzyskane dane pokazały, że bardziej preferowane są metafory typowe, niezależnie od afektu. Największą akceptacją cieszyła się metafora miłość jest podróżą. Akceptacja metafor nietypowych ma związek z twórczością emocjonalną, szczególnie w zakresie nowatorstwa emocjonalnego. Wyniki zostały poddane dyskusji w kontekście umiejętności twórców emocjonalnych do pozakonwencjonalnego rozumienia doznań emocjonalnych. Literatura wskazuje, że rozumienie „miłości jako podróży” ma negatywny wyraz emotywny. Może to potwierdzać tendencję włączania w zakres pojęcia miłości osobistych doświadczeń emocjonalnych.

Słowa kluczowe: miłość; metafora; twórczość emocjonalna; kobiety 


\section{WPROWADZENIE}

Tradycyjnie uznaje się metaforę (przenośnię) za figurę stylistyczną charakterystyczną dla języka poetyckiego. Polega ona na celowej zmianie znaczenia pól semantycznych tworzących ją wyrazów, które określa się mianem tematu i nośnika. A. Biela (1993) twierdzi, że warunkiem tworzenia metafory jest wykrycie podobieństwa między dziedzinami odnoszącymi się do tematu i nośnika w ten sposób, że nośnik mówi coś nowego o temacie, ponieważ przez swoje narzucające się aspekty zwraca uwagę na ukryte, choć ważne, cechy tematu. Jak zauważa S. Sierotwiński (1985, s. 141), „w języku potocznym i tradycji poetyckiej utrwaliło się wiele powszechnie zrozumiałych metafor, które nie mają już wartości ekspresywnej, toteż twórcy dążą do odświeżenia i wyszukiwania nowych przenośni, które wniosłyby oryginalne wartości obrazowe i uczuciowe". Właśnie w tym sensie metafora funkcjonuje w psychologii, ponieważ:

Metafory (...) od dawna były przedmiotem zainteresowania psychologów ze względu na problemy: w jaki sposób metafory są rozpoznawane i interpretowane; co odróżnia „dobrą” metaforę od „złej”; jaką rolę odgrywają one w porozumiewaniu się; w jaki sposób dzieci uczą się takich wymyślnych środków wyrazu. (Reber 2000, s. 363)

W psychologii metafora jest $\mathrm{z}$ powodzeniem wykorzystywana w modelach teoretycznych (np. przedstawiona niżej metaforyczna reprezentacja znaczenia emocji), diagnostyce (np. do badania stopnia zaburzenia myślenia w przebiegu chorób neurodegradacyjnych), interwencji (np. transakcja metaforyczna jako narzędzie oddziaływań psychokorekcyjnych w terapii; Soroko 2006) czy w obszarze twórczości (np. umiejętność metaforyzowania jako podstawowy przejaw aktywności twórczej; Nęcka 1992). W ostatnim z wymienionych obszarów metafora jest określana jako „stymulator twórczości”. Nie tylko generowanie metafor, ale także ich dekodowanie stanowi wykładnik twórczości. Takie podejście do metafory i metaforyzowania jest możliwe dzięki egalitarnemu rozumieniu twórczości (Nęcka 2001), w ramach którego kreatywność jest traktowana jako zjawisko powszechne, podobne do innych procesów poznawczych, występujące u wszystkich ludzi. Choć język ogranicza ludzkie poznanie, to zarazem daje możliwość (m.in. dzięki metaforze), przy wystarczająco zaawansowanej reinterpretacji, wyrażenia stanów wykraczających poza jego dosłowność (por. produktywność językowa prowadząca do kreatywności: Nęcka, Orzechowski, Szymura 2006, s. 503-504).

\section{MODEL METAFORYCZNY ROZUMIENIA EMOCJI}

Na szczególną uwagę z punktu widzenia niniejszej pracy zasługuje wykorzystanie metafory jako jednej z form znaczenia emocjonalnego. Model metaforycz- 
ny zaliczany jest do grupy modeli leksykalnych i uwzględnia takie figury stylistyczne, jak metafora i metonimia (Kövecses 2000; Nowakowska-Kempna 2000a; White 2005; Lakoff, Johnson 2010; Jasielska 2013). Podejście to jest szczególnie popularne wśród językoznawców, którzy są przekonani, że zastosowanie metafory umożliwia bardziej niuansowy wgląd w rozumienie emocji. Mimo że metafora jest przede wszystkim zjawiskiem językowym, to z powodzeniem odzwierciedla procesy społeczno-kulturowe, neuronalne i cielesne (por. Kövecses 2011, 2013). Dzięki procesom poznawczym, opartym na analogii i wyobraźni, ma ona przejrzystą budowę i najlepiej utrwala różne sposoby konceptualizacji (Mikołajczuk 1994, 1999), dzięki czemu jest predysponowana do objaśniania emocji i wykorzystywana do językowego obrazowania. Dzieje się tak, ponieważ emocje są słabo różnicowane w doświadczeniu, a dzięki metaforze utrwalają się w systemie poznawczym za pośrednictwem zjawisk o bardziej wyrazistej strukturze, jak np. kategorie przestrzenne czy „cielesne”.

Literatura przedmiotu dostarcza bogatej charakterystyki ujęć metaforycznych pojedynczych emocji, zarówno podstawowych (np. złość, radość), jak i złożonych (np. szczęście, duma) (Kövecses 1986, 2000, 2008; Mikołajczuk 1999, 2009; Nowakowska-Kempna 2000b; Wiśniewska-Kin 2009; Lakoff, Johnson 2010), których omówienie wykracza poza ramy tego opracowania. Warto jednak zauważyć, że niektóre ogólne metafory są często stosowane do większości emocji pozytywnych i negatywnych, np. metafora wulkanu znajduje egzemplifikacje w wypowiedziach: Byta przepetniona smutkiem i Jeśli nie pozwolisz ujść swoim emocjom, to eksplodujesz, a metafora choroby w: Opętat go szat radości i Stracit rozum z rozpaczy (Averill 1990; Saarni 1999).

\section{TWÓRCZOŚĆ EMOCJONALNA}

Przedstawione wyżej prawidłowości ogólne dotyczące kognitywnego rozumienia metafory w procesie twórczym oraz jej specyficznego zastosowania w obszarze rozumienia znaczenia emocjonalnego korespondują z cechą indywidualną, jaką jest twórczość emocjonalna. Pojęcie to zostało wprowadzone do psychologii przez J.R. Averilla (1999a), reprezentanta społecznego konstruktywizmu w powstawaniu emocji. Autor zdefiniował kreatywność emocjonalną jako zdolność do przeżywania emocji w wysoce spersonalizowany, idiosynkratyczny sposób, tak aby dać wyraz własnej indywidualności oraz kontestować standardy emocjonalne obecne w danym społeczeństwie czy kulturze (por. Jasielska 2002; Trzebińska 2008). Ma ona charakter stopniowalny. Na najniższym poziomie twórczość emocjonalna przejawia się w szczególnie efektywnym przeżywaniu emocji, która istnieje w obrębie danego społeczeństwa, kultury. Na wyższym poziomie chodzi o przeżywanie zmodyfikowanych standardowych emocji, tak by lepiej wyrażały potrzeby jednostki lub grupy. Na poziomie najwyższym dochodzi do doświad- 
czania nowej emocji, wynikającej ze zmian w przekonaniach i zasadach, na podstawie których emocje są ustanowione (Averill 1999b, s. 334). Chodzi o to, aby jednostka w swoim przeżyciu przekształcała przyjęte społeczne reguły dotyczące wzorców reagowania emocjonalnego (Averill 2004). Za twórcze zmiany w zakresie doświadczeń emocjonalnych uznaje się te, które spełniają trzy kryteria. Po pierwsze, doświadczana emocja jest nowa w porównaniu do dotychczasowych przeżyć jednostki lub w odniesieniu do szerokich oczekiwań społecznych. Po drugie, emocja jest adekwatna, trafna w stosunku do okoliczności, które ją wzbudziły. Po trzecie, jest autenty czna, czyli odzwierciedla osobiste przekonania i wartości jednostki, nie jest reakcją na oczekiwania innych ${ }^{1}$.

Badania dowiodły, że twórczość emocjonalna nie koresponduje z twórczością poznawczą czy innymi zdolnościami umysłowymi (Dudek 2017; Skrodzka 2017). Potwierdzono trzy kluczowe aspekty twórczości emocjonalnej: gotowość, nowatorstwo i efektywność/autentyczność (Averill, Thomas-Knowles 1991). Okazało się, że kobiety są bardziej twórcze emocjonalnie od mężczyzn (Jasielska 2002), podobnie jak osoby posiadające rodzeństwo od jedynaków (Andrzejak 2016). Nie zaobserwowano natomiast związku twórczości emocjonalnej z wiekiem (Udzik 2017). Osoby twórcze emocjonalnie są uważane przez swoich przyjaciół za bardziej emocjonalnie kreatywne w codziennych sytuacjach (Averill 2011). W sytuacji wywołującej stres jednostki twórcze emocjonalnie używają strategii radzenia sobie związanych z samokontrolą i poszukiwaniem wsparcia społecznego, a w przypadku stresu mniejszościowego są bardziej skłonne do ujawniania swojej orientacji i nie ukrywania się (Wiśniewska 2017). Choć twórcy emocjonalni mają czasem trudności z opisywaniem swoich uczuć, tak jak osoby aleksytymiczne, to źródeł tych trudności poszukuje się w obszarze nadmiernej złożoności doświadczeń emocjonalnych, a nie w zaburzeniach związanych z opisem uczuć (Fuchs, Kumar, Porter 2007). Wydarzenia traumatyczne czy krytyczne mogą predyspono-

1 Podobnych cech wytworu twórczego dostarcza model komplementarnie dobranych kryteriów twórczości zaproponowany przez E. Nęckę (1994). Do cech twórczego wytworu zaliczono: 1) trafność, czyli zaspokojenie przez wytwór potrzeby materialnej lub intelektualnej. W bardziej liberalnym ujęciu trafność wiąże się z faktem, iż wytwór jest sensowny, tj. coś dla kogoś znaczy; 2) oryginalność, czyli wolność od naśladownictwa, przede wszystkim autoplagiatu; 3) niezwykłość, czyli rzadkość występowania podobnych wytworów w danej kulturze czy zbiorowości; 4) konieczność, czyli fakt, że dany wytwór wcześniej czy później musi się pojawić, choć niekoniecznie w jakiejś konkretnej formie, jako dzieło konkretnego człowieka; 5) wartość estetyczna jako miara „elegancji” każdego wytworu. Nęcka (1994, s. 20) uważa przy tym, że „,niektóre z tych kryteriów są konieczne (np. trafność), inne można najwyżej uznać za fakultatywne (np. wartość estetyczną). Jednak posługiwanie się wszystkimi kategoriami łącznie może stanowić ocenę wytworu, a w każdym razie ją zobiektywizować”. 
wać osobę do twórczości emocjonalnej, czego dowodem jest związek twórczości emocjonalnej z wzrostem potraumatycznym (Bączek 2018). Ponadto osoby twórcze emocjonalnie są bardziej skłonne do doświadczeń mistycznych, są pewne swoich umiejętności i mniej podatne na wpływ tradycji i autorytetów (Averill 1999b). W zakresie cech osobowości twórczość emocjonalna koreluje z otwartością na doświadczenie, przy czym nowatorstwo - z neurotyzmem, a efektywność - z ekstrawersją (Averill, Nunley 1992).

Można przypuszczać, że twórczości emocjonalnej towarzyszy niekonwencjonalny sposób zarówno przeżywania, jak i rozumienia emocji. Chodzi w nim m.in. o wielowymiarową percepcję emocji, w ramach której jednostka np. przekracza ewaluacyjną dwudzielność przyjemne - nieprzyjemne emocje (Jasielska 2015). Być może to właśnie osoby emocjonalnie kreatywne są gotowe mówić o „dobrej złości”, którą przeżywają dojrzale i zdrowo (Kubiak 2011), czy „przyjemnym strachu”, gdy „Strach, który przychodzi z zewnątrz, strach narzucony tobie jest upokorzeniem. Ale strach, który sam sobie wybierasz, to jest ogromna przyjemność, radość, poczucie jakiejś szlachetnej gry o życie" (Kott 2000), a także zatytułować obraz malarstwa abstrakcyjnego jako „uspokajająca zawiść” (Jasielska 2015).

W koncepcji twórczości emocjonalnej postuluje się z jednej strony zdolność jednostki do doświadczania twórczych emocji, z drugiej zaś kreatywne, poznawcze opracowywanie tego doświadczenia, dzięki czemu koncepcja ta łączy w sobie dwie domeny: emocji i rozumienia emocji (White 2005). Choć nie wszystkie badania nad twórczością emocjonalną dostarczają danych świadczących o korespondencji twórczości emocjonalnej z zaawansowanym poznawczym opracowaniem emocji (Skrodzka 2017; Jaskulska 2018), to np. do pomiaru twórczości emocjonalnej stosuje się narzędzia wykorzystujące przetwarzanie poznawcze, np. Test Triad Emocjonalnych (Emotional Triads Test) (Averill, Thomas-Knowles 1991). Polega on na napisaniu historii, w której trzy niekongruentne emocje są połączone w pojedyncze, ujednolicone doświadczenie. Przykładowe triady emocjonalne to: „spokój, zdezorientowanie, impulsywność” oraz „samotność, złość, radość". Przedmiotem oceny jest specyficznie definiowany w ramach twórczości emocjonalnej stopień, w jakim historia jest nowatorska, efektywna (adaptacyjna), autentyczna, zintegrowana i kreatywna. Na podstawie konstrukcji testu można wnioskować, że jedną z miar twórczości emocjonalnej jest umiejętność atypowego łączenia ze sobą różnych doświadczeń emocjonalnych, tradycyjnie definiowanych jako odrębne czy niezależne.

\section{PSYCHOLOGICZNE KONCEPCJE MIŁOŚCI}

W Słowniku psychologii miłość jest definiowana jako trwałe intensywne uczucie sympatii i przywiązania do określonej osoby, połączone z pragnieniem przebywania z nią i troską o jej szczęście i zadowolenie (Reber 2000, s. 372). R.J. Sternberg (2001) 
z kolei sklasyfikował miłość jako szczególnie złożone i zindywidualizowane uczucie o pozytywnym charakterze. Jak wynika z tego opisu, miłość jest uczuciem o walencji jednoznacznie pozytywnej. Tymczasem, definiując podstawowy temat relacyjny miłości, R. Lazarus (1998, s. 148) twierdzi, że jest nim „pozostawanie w związku z taką osobą lub takie pragnienie, zwykle, choć niekoniecznie odwzajemniane". Widać zatem, że zakres pojęcia miłości nie jest jednolity i mogą do niego być włączone elementy o walencji negatywnej (por. afektonimy: Bańko, Zygmunt 2011). Wielu teoretyków postuluje taki stan rzeczy i opisuje miłość jako ukonstytuowaną równocześnie z samopoświęcenia, zainteresowania, tęsknoty i czułości (Wojciszke 2003; Skubalanka 2007). Ponadto miłość (podobnie jak zazdrość) uznaje się za przykład tzw. emocji „słodko-gorzkiej” (Ogarkova 2007, s. 95; Magai 2008, s. 384).

Podobna tendencja pojawiła się $\mathrm{w}$ badaniach potocznego rozumienia emocji. W badaniach polskiego leksykonu emocji (Jasielska 2013) w kategorii miłości ujawniły się trzy subkategorie dotyczące: 1) aspektu seksualnego miłości (np. pragnienie, uniesienie, ekstaza, podniecenie); 2) aspektu uczuciowego (np. czułość, oczarowanie, umiłowanie, zakochanie); 3) aspektu dramatycznego (np. tęsknota, troska, nadzieja, zazdrość). Ambiwalentny charakter mają również skrypty miłości posiadane przez osoby psychopatyczne (Gawda 2011), w których aktor skryptu doświadcza zarówno radości i szczęścia, jak i smutku i złości. Podobnie rzecz się ma w badaniach wykorzystujących technikę fluencji werbalnej, w których okazało się, że miłość może być np. postrzegana jako pozbawiona poczucia bezpieczeństwa osoby z podwyższonym lękiem osobowościowym czy jako ograniczenie wolności przez osoby będące w związku (Gawda 2017).

O złożoności uczucia miłości może świadczyć także fakt, że literatura przedmiotu wskazuje na istnienie kilku jej typów. Istnieje: miłość oparta na przywiązaniu, którą potomstwo darzy opiekunów; miłość rodzicielska (tzw. opiekuńcza); miłość przyjacielska; miłość partnerska, w kulturze euro-amerykańskiej określana jako romantyczna; miłość seksualna (inaczej intymna) (Sternberg, Weis 2007). Za najbardziej prototypowy z rodzajów miłości została uznana miłość partnerska, która jest powiązana z większym zadowoleniem ze związku niż miłość namiętna, która jest mniej prototypowa (Fehr 2007).

\section{PROBLEMATYKA BADAŃ WŁASNYCH}

Na podstawie powyższych rozważań podjęto próbę zweryfikowania sposobu potocznej konceptualizacji miłości i jej związku z twórczością emocjonalną. W badaniach oparto się na założeniach wynikających ze studiów teorio-poznawczych:

- miłość jest postrzegana jako stan uczuciowy złożony i niejednorodny, dla którego charakterystyczne jest doznanie o walencji pozytywnej, a w zakresie jego rozumienia są obecne elementy wartościowane negatywnie (np. zdrada, zawód miłosny itp.), 
- jedną z form reprezentacji emocji jest metafora,

- metafora, z racji swojej charakterystyki, umożliwia wyrażenie nowego znaczenia emocji przy użyciu dobrze znanych słów (m.in. dzięki procesom metaforyzowania czy abstrahowania), których - choć są przekształceniami mentalnymi i jako takie zachodzą poza językiem - efektem są wypowiedzi słowne. $Z$ jednej strony jest to definiowanie i redefiniowanie emocji poprzez akcentowanie pewnych aspektów i ignorowanie innych, z drugiej zaś nazywanie zjawisk emocjonalnych z wykorzystaniem cech innego zjawiska. Dzięki tym zabiegom można nazywać emocje lub je klasyfikować w taki sposób, aby przekazać trudne do wyrażenia cechy,

- twórczość emocjonalna sprzyja przeżywaniu i reprezentowaniu emocji w sposób niekonwencjonalny, choć trafny w stosunku do warunków intra- i interpersonalnych.

Postawiono następujące hipotezy:

H1: Typowe metafory miłości są akceptowane bardziej niż nietypowe metafory miłości, niezależnie od aktualnie doświadczanego afektu.

H2: Istnieje związek między twórczością emocjonalną i akceptowaniem metafor miłości.

\section{METODA}

Materiał. Na potrzeby badania stworzono 30 metafor (Pajęcka 2017) o takiej samej strukturze, w formie zdania oznajmującego, które przyjęło postać Mitość jest jak... (Wiśniewska-Kin 2009; por. ćwiczenie metaforyzowania w ramach treningu twórczości: Nęcka 1992, s. 87-88).

Wykorzystana konstrukcja miała postać porównania (wskaźnik jak), które można uogólnić w kategoriach meta: „(...) brać A za B, to zrozumieć, że rzekome (mniemane) B to A" (Wierzbicka 1971, s. 139). Tematem metafory, abstrakcyjną domeną docelową, była miłość o denotacji pozytywnej, a nośnikiem - rzeczownik o emotywnej konotacji pozytywnej lub negatywnej, dzięki czemu powstało 15 typowych i 15 nietypowych metafor.

W celu ujednolicenia poszczególnych nośników posłużono się wystandaryzowanym leksykonem. Poszukując nośników metafor, posiłkowano się polską Listą Wyrazów Afektywnych stworzoną w Instytucie Nenckiego (Nencki Affective Word List - NAWL) (Riegel i in. 2015). NAWL jest adaptacją kulturową Berlińskiej Listy Wyrazów Afektywnych (BAWL-R). Baza zawiera blisko trzy tysiące słów występujących w języku polskim, w tym rzeczowników, czasowników i przymiotników wraz z wystandaryzowanymi ocenami ich walencji emocjonalnej (przyjemność - brak przyjemności), pobudzenia (pobudzenie - brak pobudzenia) oraz potencjału wyobrażeniowego, rozumianego jako łatwość wyobrażenia sobie tego, co opisuje dane słowo. NAWL określana jest także jako nowa me- 
toda klasyfikacji stymulatorów emocjonalnych, która powstała dzięki założeniu, że dane słowo należy do danej kategorii emocji, jeśli jego średnia ocena dla tej kategorii jest wyższa niż w przypadku pozostałych kategorii. Wskaźniki informują o tym, jak oceniane są dane wyrazy w kategoriach: szczęście, złość, smutek, strach i wstręt, a zatem dostarczają wiedzy na temat ich specyficznego znaczenia emotywnego.

Tworząc metafory na potrzeby tej pracy, skorzystano z listy zawierającej wyłącznie odpowiedzi kobiet i ich oceny wyrazów w kategoriach pięciu podstawowych emocji. Biorąc pod uwagę te wyrazy, które osiągają najwyższe wskaźniki w danej kategorii i jednocześnie mogą - nawet w bardzo odległy sposób - kojarzyć się z tematyką miłości, uzyskano listę 71 słów. W następnym etapie wszystkie słowa poddano bardziej krytycznej ocenie pod względem ich adekwatności jako nośnika tematu miłości, odwołując się m.in. do literatury przedmiotu (por. Kövecses 1986, 2000; Olekszyk 2007; Połowniak-Wawrzonek 2007; Skubalanka 2007), oraz dokonano ponownej selekcji formalnej, m.in. usunięto niektóre wyrazy zbieżne znaczeniowo oraz słowa niebędące rzeczownikami. Nie zawsze bezkrytycznie kierowano się wynikami NAWL, np. słowo poduszka $(5,36)$ wyparło znacznie wyżej oceniony w kategorii szczęście sen $(5,71)$. Wyrazy pochodzące z kategorii szczęście (np. śmiech z wynikiem 6,79) zaklasyfikowano jako nośniki pozytywne, a pozostałe (należące do kategorii złość, smutek, strach, wstręt) jako nośniki negatywne (np. awantura $\mathrm{z}$ wynikiem $6,45 \mathrm{w}$ kategorii złość). W ten sposób uzyskano 17 nośników pozytywnych i 18 negatywnych. W toku dalszych analiz usunięto z listy m.in. jedwab, uznając ten wyraz za zbyt odległy znaczeniowo pomimo stosunkowo wysokiego wyniku w kategorii szczęście $(5,07)$. Niższy wynik w tej samej kategorii uzyskał wyraz poezja $(5,00)$, który pozostał na liście nośników pozytywnych. W tworzeniu metafor nie chodziło o przypadkowość, lecz o rozwagę, ponieważ metaforyzacja nie może naruszyć ani struktury domeny docelowej, ani jej ładunku aksjologicznego. Jak przestrzega T.P. Krzeszowski, może to prowadzić do gry językowej, która polega na szukaniu skojarzeń:

Ze słownika na chybił trafił wybieramy jakiś rzeczownik, a za nim następny, i podstawiamy je do naszej formuły X to Y. Na przykład swędzenie to formacja, małpa to trawnik, domator to znak, miłość to kołek w płocie, życie to guzik. Możemy się tak bawić w nieskończoność, doszukując się analogii pomiędzy tymi pojęciami. Na przykład miłość to kołek w płocie, bo zawsze tkwi obok innego kołka (...). Ale czy o takie eksperymenty z nazwami chodzi? (Krzeszowski 2006, s. 46)

W efekcie końcowym uzyskano stwierdzenia poprawne w sensie syntaktycznym oraz w połowie nietypowe w zakresie walencji. Powstałe metafory - ze względu na pełnioną funkcję kognitywną (Lakoff, Johnson 2010) - mają częściowo postać metafor ontologicznych, ujmujących doświadczenie człowieka w kategoriach pewnych rzeczy czy substancji (Wiśniewska-Kin 2009, s. 35) (np. mitość 
jest jak szampan, miłość jest jak sznur) lub strukturalnych, odwołujących się do doświadczeń o charakterze egzystencjalnym (Wiśniewska-Kin 2009, s. 36) (np. miłość jest jak sztorm, miłość jest jak podróż). Biorąc pod uwagę kryterium konwencjonalności (por. koherencja kulturowa: Lakoff, Johnson 2010, s. 51-54), należy stwierdzić, że utworzone metafory miłości są bardzo zróżnicowane - w badaniu wystąpiły zarówno te wysoce konwencjonalne (np. wspomniana miłość jest jak podróż), jak i niekonwencjonalne (np. miłość jest jak awantura).

$\mathrm{W}$ ostatnim etapie tworzenia zestawu metafor 15 nośników dla obu kategorii poddano losowemu przyporządkowaniu do pozycji w kwestionariuszu. Zadaniem osoby badanej była ocena stopnia, w jakim zgadza się z przesłaniem poszczególnej metafory. Posłużyła do tego skala Likerta, gdzie 1 oznaczało „zdecydowanie się nie zgadzam”, a 5 - „zdecydowanie się zgadzam”. Badanie obrazowało tendencję osoby badanej do zgadzania się ze znaczeniem metafor typowych o nośniku emotywnie pozytywnym oraz metafor nietypowych o nośniku emotywnie negatywnym. Po zsumowaniu punktów przyznanych poszczególnym kategoriom nośników otrzymano wyniki dla dwóch skal, które nazwano: metafory typowe (pozytywne; alfa Cronbacha $=0,83$ ) i metafory nietypowe (negatywne; alfa Cronbacha $=0,88)$. W każdej skali można było zdobyć minimalnie 15 punktów, a maksymalnie -75 punktów.

\section{NARZĘDZIA BADAWCZE}

Skala Pozytywnego i Negatywnego Afektu. Do monitorowania subiektywnego natężenia dominującego afektu pozytywnego i negatywnego w aktualnym doświadczeniu uczestniczki badania wykorzystano Skalę Pozytywnego i Negatywnego Afektu (Positive and Negative Affect Schedule - PANAS) (Watson, Clark, Tellegen 1988) w eksperymentalnej wersji Ł. Kaczmarka. Skala składa się z 20 przymiotników będących opisem doświadczenia afektywnego, w tym 10 przymiotników tworzy skalę afektu pozytywnego (alfa Cronbacha $=0,68$ ), a pozostałe 10 - skalę afektu negatywnego (alfa Cronbacha $=0,83$ ). Zadaniem osoby badanej jest określenie na 5-stopniowej skali, jak czuje się w chwili obecnej, gdzie 1 oznacza „wcale lub nieznacznie”, a 5 - „wyjątkowo mocno”.

Inwentarz Twórczości Emocjonalnej. Do pomiaru twórczości emocjonalnej zastosowano Inwentarz Twórczości Emocjonalnej (Emotional Creativity Inventory - ECI) (Averill 1999b) w eksperymentalnej wersji A. Jasielskiej (2002). Narzędzie ma formę kwestionariusza samoopisowego składającego się z 30 stwierdzeń (w tym dwa odwrotnie punktowane). Zadaniem osoby badanej jest określenie stopnia, w jakim stwierdzenie ją opisuje. Służy do tego 5-ciostopniowa skala, gdzie 1 oznacza „w ogóle mnie nie opisuje”, a 5 - „w pełni mnie opisuje". Poza miarą twórczości emocjonalnej (alfa Cronbacha $=0,88$ ) uzyskuje się wyniki dla jej trzech składowych: gotowości (siedem pozycji, np. Myślę i pró- 
buję zrozumieć moje reakcje emocjonalne; alfa Cronbacha $=0,82)$, nowatorstwa (14 pozycji, np. Mam doświadczenia emocjonalne, które uważa się za niezwykłe; alfa Cronbacha $=0,87$ ), efektywności/autentyczności (dziewięć pozycji, np. Moje emocje pomagaja mi osiagnać moje cele $w$ życiu; alfa Cronbacha $=0,79$ ).

Uczestnicy badania. Zaproszenie do udziału w badaniu było skierowane do kobiet, które ukończyły 25. rok życia. W rezultacie w przeprowadzonym badaniu wzięły udział 43 kobiety w wieku od 25 do 58 lat $(\mathrm{M}=30,6 ; \mathrm{SD}=8,9)$, w tym: $65 \%$ posiadało wykształcenie wyższe, $35 \%$ - wykształcenie średnie; $46 \%$ zadeklarowało, iż są w związku partnerskim, 33\% - w związku małżeńskim, 21\% to tzw. singielki; $55 \%$ badanych wskazało jako miejsce zamieszkania miasto powyżej 500 tys. mieszkańców, 28\% - wieś, 9\% - miasto 100-500 tys. mieszkańców, 7\% - miasto do 10 tys. mieszkańców, 2\% - miasto 10-50 tys. mieszkańców.

Przebieg badania. Badania zostały zrealizowane online. Przygotowano kwestionariusz internetowy, do którego link (umożliwiający rozpoczęcie badania) został udostępniony na wybranych portalach społecznościowych. W zaproszeniu do wzięcia udziału w badaniu poinformowano, że kierowane jest ono wyłącznie do kobiet, które ukończyły 25 lat. Zadaniem uczestniczki badania, po wyrażeniu zgody, było uzupełnienie metryczki z danymi demograficznymi, a następnie Skali Pozytywnego i Negatywnego Afektu (PANAS). W dalszej kolejności były oceniane metafory dotyczące miłości, a na zakończenie należało wypełnić Inwentarz Twórczości Emocjonalnej.

\section{WYNIKI}

W celu weryfikacji pierwszej hipotezy, mówiącej o tym, że typowe metafory emocji są akceptowane bardziej niż nietypowe metafory miłości niezależnie od aktualnie doświadczanego afektu, w pierwszej kolejności dokonano analizy korelacji między afektem pozytywnym i negatywnym a akceptacją metafor. Analiza wykazała brak istotnych statystycznie związków między zmiennymi. Należy więc stwierdzić, że akceptowanie przez uczestniczki badania określonych metafor nie zależało od ich stanu afektywnego.

Następnie dokonano analizy testem t-Studenta dla prób niezależnych, która wykazała, że typowość nośnika metafory wpływa na akceptowanie metafor miłości: $\mathrm{t}(84)=12,08 ; \mathrm{p}<0,001$. Akceptacja metafor typowych okazała się istotnie statystycznie wyższa $(\mathrm{M}=55,63 ; \mathrm{SD}=9,32)$ niż akceptacja metafor nietypowych $(\mathrm{M}=30,26 ; \mathrm{SD}=10,15)$. Wielkość efektu (d Cohena $=2,62)$ wskazuje na silny związek między rodzajem nośnika metafory a jej akceptacją.

Analiza średnich akceptacji dla poszczególnych metafor (tab. 1) pokazała, że spośród metafor typowych najbardziej preferowana była metafora miłość jest jak podróż, a najmniej metafora miłość jest jak skowronek. 
Tab. 1. Średnie oszacowania dla metafor typowych

\begin{tabular}{|c|c|c|}
\hline Metafora typowa & M & SD \\
\hline Miłość jest jak podróż & 4,51 & 0,70 \\
\hline Miłość jest jak skarb & 4,44 & 0,73 \\
\hline Miłość jest jak schronienie & 4,12 & 1,13 \\
\hline Miłość jest jak śmiech & 3,93 & 1,24 \\
\hline Miłość jest jak pieszczota & 3,88 & 0,95 \\
\hline Miłość jest jak piosenka & 3,88 & 1,13 \\
\hline Miłość jest jak dar & 3,74 & 1,02 \\
\hline Miłość jest jak błękit nieba & 3,70 & 1,22 \\
\hline Miłość jest jak światło gwiazd & 3,70 & 1,16 \\
\hline Miłość jest jak ogród & 3,67 & 1,21 \\
\hline Miłość jest jak taniec & 3,63 & 1,21 \\
\hline Miłość jest jak szampan & 3,16 & 1,32 \\
\hline Miłość jest jak pralina & 3,14 & 1,39 \\
\hline Miłość jest jak poduszka & 3,07 & 1,37 \\
\hline Miłość jest jak skowronek & 3,05 & 1,19 \\
\hline
\end{tabular}

Źródło: opracowanie na podstawie: (Pajęcka 2017).

Z kolei spośród metafor nietypowych (tab. 2) najbardziej akceptowana była metafora milość jest jak sztorm, a najmniej metafora miłość jest jak koszmar.

Tab. 2. Średnie oszacowania dla metafor nietypowych

\begin{tabular}{|c|c|c|}
\hline Metafora nietypowa & M & SD \\
\hline Miłość jest jak sztorm & 3,23 & 1,19 \\
\hline Miłość jest jak heroina & 3,12 & 1,34 \\
\hline Miłość jest jak lawina & 2,91 & 1,30 \\
\hline Miłość jest jak łza & 2,44 & 1,11 \\
\hline Miłość jest jak choroba & 2,07 & 1,29 \\
\hline Miłość jest jak pułapka & 2,05 & 1,32 \\
\hline Miłość jest jak gorzki syrop & 2,00 & 1,17 \\
\hline Miłość jest jak krzyk & 1,74 & 1,00 \\
\hline Miłość jest jak awantura & 1,67 & 1,06 \\
\hline Miłość jest jak więzienie & 1,63 & 0,97 \\
\hline Miłość jest jak niewolnica & 1,63 & 0,90 \\
\hline Miłość jest jak sznur & 1,58 & 0,93 \\
\hline Miłość jest jak tortura & 1,56 & 1,03 \\
\hline Miłość jest jak knebel & 1,33 & 0,71 \\
\hline Miłość jest jak koszmar & 1,30 & 0,80 \\
\hline
\end{tabular}

Źródło: opracowanie na podstawie: (Pajęcka 2017). 
W celu zweryfikowania hipotezy drugiej, mówiącej o tym, że istnieje związek między twórczością emocjonalną i akceptowaniem metafor miłości, przeprowadzono analizę korelacji, której wyniki znajdują się w tab. 3.

Tab. 3. Związki między twórczością emocjonalną a akceptowaniem metafor

\begin{tabular}{|c|c|c|c|c|}
\hline & $\begin{array}{c}\text { Twórczość } \\
\text { emocjonalna }\end{array}$ & Gotowość & Nowatorstwo & Efektywność \\
\hline Akceptacja metafor typowych & $0,32^{*}$ & $0,36^{*}$ & 0,25 & 0,17 \\
\hline Akceptacja metafor nietypowych & $0,46^{* *}$ & 0,19 & $0,61 * *$ & 0,05 \\
\hline
\end{tabular}

$* \mathrm{p}<0,05 ; * * \mathrm{p}<0,01$

Źródło: opracowanie własne.

Uzyskane statystyki wskazują na istnienie dodatniej słabej zależności między akceptowaniem metafor typowych i nietypowych a twórczością emocjonalną. W przypadku akceptacji metafor nietypowych związek ten okazał się nieco silniejszy, jednak dokonanie analizy porównawczej z zastosowaniem transformacji r-do-z Fishera nie wykazało istotnej różnicy w sile związków. Również między gotowością a akceptacją metafor typowych wystąpił słaby związek dodatni. Natomiast między nowatorstwem a akceptacją metafor nietypowych miał miejsce związek dodatni o umiarkowanej sile.

Dla doprecyzowania obrazu uzyskanych zależności przeprowadzono analizę korelacji dla poszczególnych metafor i twórczości emocjonalnej. Wśród 15 metafor typowych zaobserwowano związki istotne statystycznie jedynie dla dwóch: mitość jest jak taniec $(\mathrm{r}=0,33 ; \mathrm{p}<0,05)$ oraz mitość jest jak piosenka $(\mathrm{r}=0,39$; $\mathrm{p}<0,05)$. Natomiast dla metafor nietypowych związki istotne odnotowano dla sześciu: miłość jest jak choroba $($ rho $=0,35 ; \mathrm{p}<0,05)$, miłość jest jak heroina $(\mathrm{rho}=0,36 ; \mathrm{p}<0,05)$, miłość jest jak sznur ( $\mathrm{rho}=0,36, \mathrm{p}<0,05)$, miłość jest jak sztorm (rho $=0,47 ; \mathrm{p}<0,01)$, mitość jest jak awantura $(\mathrm{rho}=0,32 ; \mathrm{p}<0,05)$, miłość jest jak koszmar ( $\mathrm{rho}=0,31, \mathrm{p}<0,05)$.

\section{DYSKUSJA}

Hipoteza mówiąca o większej preferencji metafor typowych została potwierdzona. Bardziej akceptowano metafory miłości, w których temat i nośnik były koherentne w zakresie pozytywnej walencji emocjonalnej. Widać zatem, że potoczny sposób rozumienia miłości odzwierciedla znak, jaki towarzyszy jej doznawaniu. Mniejsza preferencja metafor nietypowych, gdzie nośnik był obdarzony walencją negatywną, ilustruje zjawisko odwrotne. To, że preferencje określonych metafor nie były związane z aktualnie doświadczanym afektem osób dokonujących oceny metafor, świadczy o tym, że system reprezentacji poznawczej, której wyrazem są m.in. metafory językowe, jest niezależny od chwilowych doznań. W efekcie wi- 
dać, że „wtórne” struktury interpretacyjne są nadbudowane nad pierwotnym fizjologiczno-somatycznym afektem i stanowią pośrednią miarę jego opisu. Uzyskany wynik świadczy także o tym, że system reprezentacji poznawczej emocji może mieć przynajmniej dwa poziomy reprezentacji. Pierwszy, monokonkretny, może być odzwierciedleniem doznań towarzyszących przeżywanemu stanowi afektywnemu (tu w postaci preferowania typowych metafor miłości), a drugi, polikonkretny (np. językowy²), może być odzwierciedleniem wyabstrahowanej pozakontekstowej wiedzy człowieka na temat emocji (tu w postaci braku związku między preferowaniem metafory miłości a dyspozycyjnym doznaniem emocjonalnym).

Podczas weryfikacji hipotezy mówiącej o wystąpieniu związku między twórczością emocjonalną a akceptacją metafor uzyskano niejednoznaczne zależności. Twórczość emocjonalna jest współzmienna $\mathrm{z}$ akceptacją metafor miłości niezależnie od ich charakteru. Może to wynikać z faktu, że procesy symbolizacji i metaforyzacji (Maruszewski, Ścigała 1998; Jasielska [w druku]) są wykorzystywane do wyrażania głębokich odczuć, niemożliwych do wyeksplikowania przy pomocy dosłownego ujęzykowionego pojęcia (por. metaforyka w przestrzeni mentalnej: Nowakowska-Kempna 2000b, s. 88). Ponadto zauważono, że twórca emocjonalny preferuje niespójność, a nawet konflikt między percepcją a pojęciem (Averill, Thomas-Knowles 1991). Być może właśnie dlatego zależność między akceptacją metafor nietypowych jest wyższa niż akceptacja metafor typowych. Wyższa aprobata dla tych pierwszych, które opierają się na konflikcie pomiędzy pozytywną walencją tematu i negatywną walencją nośnika, wymaga lepszej tolerancji dysonansu między nimi i dostrzeżenia w nich sensu, który wychodzi poza klasyczną definicję pojęć tworzących metaforę. Na korzyść tej interpretacji przemawia fakt, że wyższej twórczości emocjonalnej towarzyszy wyższa akceptacja dla większej puli pojedynczych metafor nietypowych.

Zależności między poszczególnymi wymiarami twórczości emocjonalnej a akceptacją metafor są mniej oczywiste. Wymiar gotowości, który był współzmienny $\mathrm{z}$ akceptacją metafor typowych, jako jedyny dotyczy stadium przygotowania (preparacji) w procesie twórczym. Dotyczy on „przedwiedzy”, z jaką jednostka rozpoczyna proces twórczy (por. schematy emocjonalne: Leahy, Tirch, Napolitano 2014). Gotowość oznacza, że jednostka poświęca uwagę swoim emocjom - interesuje się nimi, myśli o nich, jest wobec nich uważna (Averill 2011). Cecha ta nie jest specyficzna dla twórczości emocjonalnej. W takim ujęciu można ją odnaleźć także w koncepcji inteligencji emocjonalnej (Salovey, Detweiler-

2 Zastosowane nazwy kodów pochodzą z autorskiej koncepcji kod-emocje K. Obuchowskiego (2004), w której autor wyróżnił trzy poziomy kodów orientacji: monokonkretne, polikonkretne i hierarchiczne - abstrakcyjne. Układ monokonkretny organizuje informacje na zasadzie „statystyki doświadczenia”, układ polikonkretny czyni to zgodnie z zasadami językowymi, natomiast na poziomie hierarchicznym operacje wykonywane są za pomocą pojęć. 
-Bedell, Detweiler-Bedell, Mayer 2008) czy metaemocji (Hakim-Larson, Parker, Lee, Goodwin, Voelker 2006), gdzie duży nacisk kładzie się na konwencjonalny, zgodny z regułami życia społecznego, sposób rozumienia emocji. Osoba włącza się w sytuacje emotogenne z immanentną gotowością do przeżywania emocji, co jest szczególnie charakterystyczne dla kobiet (Jasielska 2002). Ponadto doświadczanie emocji jest dla niej aktywnością przyjemną i sensowną, nie stanowi narzędzia do osiągnięcia jakiegoś celu, lecz samo w sobie stanowi cel. W tym świetle zależność omawianego wymiaru twórczości emocjonalnej z preferowaniem konwencjonalnych metafor dotyczących miłości wydaje się oczywista, ponieważ dekodowanie metafor samo w sobie stanowi akt twórczy. Co więcej, zaaranżowany materiał metaforyczny ma zdecydowanie emocjonalny charakter, co tylko zdaje się potwierdzać, że osoba twórcza emocjonalnie o wysokim wyniku w skali gotowości chętnie angażuje się w aktywności związane z własną emocjonalnością.

Inną ujawnioną zależnością jest najsilniejszy z zaobserwowanych związek nowatorstwa $\mathrm{z}$ akceptacją niekonwencjonalnych metafor miłości. Nowatorstwo jest jednym $z$ podstawowych kryteriów oceny procesu twórczego $\mathrm{w}$ fazie weryfikacji (Nęcka 2001). Zdolność do generowania niestandardowych reakcji emocjonalnych może się więc przejawiać w akceptacji dla niekonwencjonalnych sposobów definiowania emocji czy też wiązać się z umiejętnością włączania w zakres pojęcia np. nietypowych konotacji (por. technika zmiany plastyczności rdzeni pojęciowych: Trzebiński 1981, s. 231) wynikających z szerokiej gamy doświadczeń miłosnych. Możliwe jest także, że osoby o wyższym natężeniu twórczości emocjonalnej potrafią spontanicznie stosować antykategorialny (konkretyzujący) postulat heurystyczny sprzyjający twórczości i neutralizujący ograniczenia poznawcze inspirowane językiem (Mudyń 1991). Polega on na rezygnacji z obowiązujących kategorii i dokonaniu nowego opisu tworzących ją egzemplarzy. Kategoryzacja bowiem opiera się na abstrakcji pozytywnej i negatywnej, czyli wyodrębnieniu cech istotnych i ignorowaniu nieistotnych. W podejściu antykategorialnym chodzi o zabieg przeciwny, czyli wyłuskanie różnic i osłabienie założenia o istnieniu pewnej szerokiej klasy obiektów opisywanej pojęciem ogólnym, co umożliwi prawdopodobnie powstanie nowych wariancji tych samych zjawisk, czego przykładem może być akceptacja nietypowej metafory miłości. Podobnie rzecz się może mieć ze spontanicznym zastosowaniem postulatu alternatywnej semantyzacji. Dotyczy on zmodyfikowania i rozszerzenia pola semantycznego pewnych zwrotów językowych, aby przezwyciężyć nawykowe skojarzenia. Chodzi o to, aby odczytać słowo w odmiennym kodzie semantycznym. „Oznacza to między innymi, że w wyrażeniach, które dotychczas traktowaliśmy w sposób dosłowny, należy doszukiwać się nierozpoznanej przez nas jeszcze metaforyczności” (Mudyń 1991, s. 30).

Analizy dodatkowe, wykraczające poza zakres weryfikacji hipotez, wskazały, że najbardziej preferowana przez uczestniczki badania była metafora mi- 
tość jest jak podróż. Mimo że w badaniach standaryzacyjnych, z których zostało zaczerpnięte słowo podróż, istnieje wskazanie, że ma ono konotację emocjonalną pozytywną, to użyte $w$ metaforze traci aż tak jednoznaczny wymiar. Być może wynika to ze zmiany znaczenia konotacyjnego słowa, kiedy wchodzi ono w związki frazeologiczne. Wprawdzie dla potrzeb badania metafora ta została przypisana do grupy metafor typowych o pozytywnej walencji, jednak literatura przedmiotu podaje, że metafora ta przekazuje znaczenia negatywne. Z. Kövecses (2000, s. 26) interpretuje tę metaforę jako „długą, wyboistą drogę”. Z kolei G. Lakoff i M. Johnson (2010, s. 79-80), dokonując jej opisu, przywołują m.in. takie wyrażenia, jak: Musimy się rozstać, Jesteśmy na rozstaju, Jesteśmy na jałowym biegu. Autorzy podkreślili, że w metaforze miłości jako podróży nie istnieje jeden konsekwentny obraz, do którego by pasowały jej wszystkie eksplikacje.

Potwierdzeniem tego, że preferowanie metafory miłość jest jak podróż jest wyrazem potocznej konceptualizacji, wychodzącej poza konwencję językową, mogą być badania S. Glucksberga, B. Keysara i M.S. McGlone’a (1992). Badacze odnieśli się do postulatów R.W. Gibbsa (1992), który - podobnie jak Lakoff i Johnson (2010) - uważał, że wypowiedzi: Zobacz kochanie, jak daleko zaszliśmy, Teraz jesteśmy na rozdrożu, Często chodzimy własnymi drogami - stanowią szczegółowe przykłady nadrzędnej konwencjonalnej metafory pojęciowej miłość jest podróżą, co oznacza, że sposób ich interpretacji ma charakter powszechny. W badaniu zaprezentowano metafory szczegółowe, m.in. Nasza miłość jest trzęsąca się kolejka górska, Nasza miłość jest wyprawa na dno morza, prosząc o ich interpretację lub sparafrazowanie. Założono, że jeżeli w organizacji tych metafor obecny jest „efekt zagnieżdżenia” (por. Maruszewski 2011), to w ich rozumieniu znajdzie się pojęcie podróży. Niestety, takie uogólnienie nie wystąpiło, wręcz przeciwnie - dostarczone przez uczestników badania interpretacje były trudne do skategoryzowania. Świadczy to o tym, że poszczególne egzemplifikacje metafory miłości jako podróży wynikają z osobistego doświadczenia jednostek i nie stanowią wyrazu uniwersalnego czy powszechnego sposobu rozumienia tego stanu uczuciowego.

Choć procedura zaplanowana w badaniu miała odmienny charakter i polegała na akceptacji zastanego znaczenia, które niesie za sobą metafora z poziomu nadrzędnego, to najwyższa zgodność pośrednio może świadczyć o udziale uniwersalnego doświadczenia w interpretacji metafor. Wiadomo, że zazwyczaj analiza znaczenia odseparowanych przykładów użycia języka (gdy Czuję się podniesiony na duchu znaczy Czuję się szczęśliwy, przykład za: Lakoff, Johnson 2010, s. 46) może sprawiać wrażenie niespójnego przekazu metaforycznego. Dopiero umieszczenie wypowiedzi we właściwym kontekście dostarcza koherentnego ujęcia znaczenia, jakie oferuje każda metafora. Interpretacja metafory, podobnie jak innych wypowiedzi językowych, wymaga systematycznego odniesienia do kontekstu sytuacyjnego, w którym się ona pojawia (por. budowa modelu sytuacyjnego i wnio- 
skowanie: Nęcka i in. 2006, s. 625), być może rozumianego także w kategoriach idiosynkratycznych. Wybór metafory podróży jako najlepiej oddającej istotę miłości może świadczyć o największej inkluzji osobistych doświadczeń zarówno pozytywnych, jak i negatywnych.

Zaaranżowany na potrzeby badania zestaw metafor typowych i nietypowych nie był wolny od błędów. Po pierwsze, kategoria metafory nietypowej jest zabiegiem technicznym przyjętym dla potrzeb badania. Metafory użyte w badaniu zostały skonstruowane, a nie zaczerpnięte z istniejących źródeł. Gdyby przyjąć za miarę typowości ich dostępność w codziennym doświadczeniu językowym, należałoby stwierdzić, że metafora miłość jest jak choroba, której egzemplifikacją są np. sformułowania chory z miłości, oszalały z miłości, umrzeć z miłości, spełnia kryteria typowości w większym stopniu niż stworzona dla potrzeb badania metafora określona jako typowa milość jest jak pralina (choć istnieje metafora, w której obiekt miłości jest uznawany za smaczne jedzenie, czego wyrazem może być wypowiedź Moja ty słodka [Kövecses 2000, s. 26], czy afektonimy zawierające nazwy słodkich smakołyków, np. czekoladko, pączusiu [Bańko, Zygmunt 2011, s. 130]). Przyjęta strategia konstruowania metafor w oparciu o NAWL doprowadziła do utworzenia nośników niekiedy dość odległych znaczeniowo od tematu miłości, mimo że aspekt ten był uważnie monitorowany. Kwestia ta dotyczy w większym stopniu nietypowych metafor miłości. W związku z tym część wykorzystanych metafor ma charakter potencjalny i nie wszystkie rzeczywiście występują w polszczyźnie. Przykładowo metafora miłość jest jak awantura (choć obecna jest metafora miłości jako „przeciwnika” [Kövecses 2000, s. 26]) mogła nastręczać trudności w jej dekodowaniu, a przez to prowadzić do odczytywania znaczenia samego nośnika, nie zaś jego związku z miłością. W istocie niekonwencjonalność metafor skonstruowanych na potrzeby badania polegała w dużej mierze na pewnym dysonansie pomiędzy dziedziną źródłową a docelową, co uzyskano m.in. poprzez manipulowanie odległością znaczeniową nośników od - utożsamianej z emocją pozytywną - miłości. Trzeba jednak przyznać, że metafory powstawały w sztucznych warunkach. Być może w niektórych przypadkach dystans znaczeniowy okazał się zbyt duży, co mogło prowadzić do zniekształceń w odczytywaniu metafor. Wreszcie istotny wydaje się również fakt dość powszechnej pozytywnej narracji towarzyszącej miłości. Miłość jest prawdopodobnie na tyle cenną wartością, że trudno ją pojmować w kategoriach doświadczenia negatywnego, stąd też mogą wynikać niskie oceny nietypowych metafor dotyczących tej emocji.

Można zadać pytanie, czy faktycznie badano metafory, a nie porównania, które są uznawane za inną strukturę nie tylko formalną, ale i konceptualną. A. Wierzbicka (1971, s. 137) z jednej strony przyznaje, że „metafora to skrócone porównanie", a z drugiej broni tezy, że metafora i porównanie różnią się od siebie. Ostatecznie jednak uznaje, że i metafora, i porównanie są wyrazem „warunko- 
wej” metajęzykowości (por. porównanie metaforyczne: Wierzbicka 1971). Wydaje się, że te rozróżnienia są istotne z punktu widzenia dyskursu poetyckiego czy językoznawczego, a nie potocznego, który był przedmiotem badania.

Zabiegiem celowym było objęcie badaniem kobiet z racji tego, że w odmienny od mężczyzn sposób pojmują emocje (Gawda 2017), przypisują afektywną konotację słowom (NAWL) oraz występują różnice międzypłciowe w twórczości emocjonalnej (Jasielska 2002). Taki wybór respondentów oraz ich niezbyt duża liczebność nakazują dużą ostrożność przy omawianiu wyników i ograniczoną możliwość ich ekstrapolowania na całą populację, a samemu badaniu pozwalają nadać status pilotażowego.

Natomiast mocną stroną przeprowadzonych badań jest tematyka dotycząca twórczości emocjonalnej, która wpisuje się w nurt dyskutowanej ostatnio kompleksowej emocjonalności (Kashdan, Barrett, McKnight 2015). Przyjmując tę perspektywę, otrzymano wstępny opis dekodowania metafory emocji przez twórców emocjonalnych.

Dalsze badania w tym zakresie mogą uwzględnić zwiększenie liczebności próby oraz włączenie do badania mężczyzn z tym samym lub innym zestawem metafor. Interesujące może być dodatkowe badanie satysfakcji ze związku, aby skontrolować wpływ osobistych przeżyć na preferowanie określonych metafor miłości. Ponadto badania można poszerzyć o dwa kolejne ujęcia, czyli „»miłość« obiekt uczucia, »miłość« postawa wobec bliźniego, drugiego człowieka” (Nowakowska-Kempna 2000b, s. 89), ponieważ w omówionych w niniejszym opracowaniu badaniach pojęcie miłości zostało ujęte wąsko - tylko jako emocja.

Przeprowadzone badania wydają się dawać asumpt do przezwyciężenia społecznych ograniczeń poznania emocji inspirowanych językiem za pomocą operacji dokonywanych na języku (Mudyń 1991, s. 20-32), kiedy posiłkujemy się metaforą językową. Dodatkowo pokazują, że istnieje grupa osób twórczych emocjonalnie, którzy są gotowi przezwyciężać te ograniczenia, chociażby pod postacią neutralizacji „łłamsicieli pomysłów”, które mogą przybrać np. formę wypowiedzi Nie widzę żadnego związku... (Nęcka 1992, s. 144). Poza tym widać, że język niekiedy może być przeszkodą $\mathrm{w}$ wyrażaniu przeżyć, co z kolei akcentuje rozbieżność dwóch domen: emocji i jej reprezentacji (White 2005; Jasielska 2013).

\section{BIBLIOGRAFIA}

Andrzejak, I. (2016). Twórczość emocjonalna i empatia a posiadanie rodzeństwa. Niepublikowana praca magisterska. Poznań: Instytut Psychologii UAM.

Averill, J.R. (1990). Inner feelings, works of the flesh, the beast within, diseases of the mind, driving force, and putting on a show: Six metaphors of emotion and their theoretical extensions. W: D.E. Leary (ed.), Metaphors in the History of Psychology (s. 104-132). New York: Cambridge University Press. 
Averill, J.R. (1999a). Creativity in the domain of emotion. W: T. Dalgleish, M.J. Power (eds.), Handbook of Cognition and Emotion (s. 765-782). London: John Wiley \& Sons.

Averill, J.R. (1999b). Individual differences in emotional creativity: Structure and correlates. Journal of Personality, 67(2), 331-371. DOI: https://doi.org/10.1111/1467-6494.00058.

Averill, J.R. (2004). A tale of two snarks: Emotional intelligence and emotional creativity compared. Psychological Inquiry, 15(3), 228-233.

Averill, J.R. (2011). Emotions and creativity. $12^{\text {th }}$ Conference "Creativity \& Innovation" (ECCI XII). Portugalia, Faro 14-17 September 2011.

Averill, J.R., Thomas-Knowles, C. (1991). Emotional creativity. W: T. Strongman (ed.), International Review of Studies on Emotion (s. 269-299). London: John Wiley \& Sons.

Averill, J.R., Nunley, E.P. (1992). Voyages of the Heart: Living an Emotionally Creative Life. New York: Free Press.

Bańko, M., Zygmunt, A. (2011). Czułe słówka. Stownik afektonimów. Warszawa: PWN.

Bączek, J. (2018). Twórczość emocjonalna u kobiet po przebytej chorobie nowotworowej doświadczajacych wzrostu potraumatycznego. Niepublikowana praca magisterska. Poznań: Wydział Zamiejscowy SWPS.

Biela, A. (1993). Psychology of Analogical Inference. Stuttgart: S. Hirzel.

Dudek, N. (2017). Twórczość poznawcza a twórczość emocjonalna-pomiar z wykorzystaniem skal samoopisowych i testów wykonania. Niepublikowana praca magisterska. Poznań: Instytut Psychologii UAM.

Fehr, B. (2007). Ukryte teorie miłości. Prototypowe podejście do badania miłości. W: R.J. Sternberg, K. Weis (red.), Nowa psychologia miłości (s. 331-360). Taszów: Biblioteka Moderatora.

Fuchs, G.L., Kumar, V.K., Porter, J. (2007). Emotional Creativity, Alexithymia, and Styles of Creativity. Creativity Research Journal, 19(2), 233-245.

DOI: https://doi.org/10.1080/10400410701397313.

Gawda, B. (2011). Skrypty miłości, nienawiści i lęku u osób antyspołecznych. Warszawa: Difin.

Gawda, B. (2017). Struktura pojęć emocjonalnych. Wykorzystanie technik fluencji werbalnej. Lublin: Wydawnictwo UMCS.

Gibbs, R.W. (1992). Categorization and Metaphor Understanding. Psychological Review, 99(3), 572-577. DOI: https://doi.org/10.1037/0033-295X.99.3.572.

Glucksberg, S., Keysar, B., McGlone, M.S. (1992). Metaphor Understanding and Accessing Conceptual Schema: Reply to Gibbs (1992). Psychological Review, 99(3), 578-581.

DOI: https://doi.org/10.1037/0033-295X.99.3.578.

Hakim-Larson, J., Parker, A., Lee, C., Goodwin, J., Voelker, S. (2006). Measuring parental meta-emotion: Psychometric properties of the emotion-related parenting styles self-test. Early Education and Development, 17(2), 229-251. DOI: https://doi.org/10.1207/s15566935eed1702_2.

Jasielska, A. (2002). Emocje a płeć. Analiza w kontekście twórczości emocjonalnej. W: A. Hulewska, A. Jasielska, M. Ziarko (red.), Interdyscyplinarne studia nad ptcia. Od polaryzacji płciowej ku depolaryzacji rodzajowej (s. 95-116). Poznań: Wydawnictwo Fundacji Humaniora.

Jasielska, A. (2013). Charakterystyka i konsekwencje potocznego rozumienia emocji. Poznań: Wydawnictwo Naukowe UAM. 
Jasielska, A. (2015). Pozadosłowne rozumienie emocji. Poznańskie Studia Slawistyczne, (9), 255274. DOI: https://doi.org/10.14746/pss.2015.9.15.

Jasielska, A. (w druku). The Representation of Models of Emotion in Damien Hirst's Works of Art. Journal of Critical Arts.

Jaskulska, A. (2018). Związek twórczości emocjonalnej z nadawaniem znaczenia konotacyjnego domenom metafory ,zielony z zazdrości”. Niepublikowana praca magisterska. Poznań: Instytut Psychologii UAM.

Kashdan, T.B., Barrett, L.F., McKnight, P.E. (2015). Unpacking emotion differentiation: Transforming unpleasant experience by perceiving distinctions in negativity. Current Directions in Psychological Science, 24(1), 10-16. DOI: https://doi.org/10.1177/0963721414550708.

Kott, J. (2000). Miłość i inne rozkosze. Wysokie Obcasy, (56), 30-40.

Kövecses, Z. (1986). Metaphors of Anger, Pride, and Love. A Lexical Approach to the Structure of Concepts. Amsterdam-Philadelphia: John Benjamins Publishing Company.

Kövecses, Z. (2000). Metaphor and Emotion: Language, Culture, and Body in Human Feeling. Cambridge: Cambridge University Press.

Kövecses, Z. (2008). The conceptual structure of happiness. W: H. Tissari, B.A. Pessi, S. Mikko (eds.), Happiness: Cognition, Experience, Language (s. 131-143). Helsinki: Helsinki Collegium for Advanced Studies.

Kövecses, Z. (2011). Język, umyst, kultura. Praktyczne wprowadzenie. Kraków: Universitas.

Kövecses, Z. (2013). Conceptualizing emotions. A cognitive lingusitic perspective. Wykład wygłoszony w ramach programu „Akademicki i Naukowy Poznań”, Poznań, 4.05.2013.

Krzeszowski, T.P. (2006). Czy istnieją niemożliwe metafory? Kilka uwag o ograniczeniach metaforyzacji. W: G. Hebrajska, J. Ślósarska (red.), Kognitywizm w poetyce i stylistyce (s. 37-46). Kraków: Universitas.

Kubiak, Ł. (2011). Foch nasz powszedni. W Drodze, (2450), 19-29.

Lakoff, G., Johnson, M. (2010). Metafory w naszym życiu. Warszawa: Wydawnictwo Aletheia.

Lazarus, R. (1998). Uniwersalne zdarzenia poprzedzające emocje. W: P. Ekman, R.J. Davidson (red.), Natura emocji (s. 146-153). Gdańsk: GWP.

Leahy, R.L., Tirch, D., Napolitano, L.A. (2014). Regulacja emocji w psychoterapii. Kraków: Wydawnictwo UJ.

Magai, C. (2008). Long-Lived Emotions. A Life Course Perspective on Emotional Development. W: M. Lewis, J.M. Haviland-Jones, L.F. Barrett (eds.), Handbook of Emotions (s. 376-392). New York: Guilford.

Maruszewski, T. (2011). Psychologia poznania. Umyst i świat. Gdańsk: GWP.

Maruszewski, T., Ścigała, E. (1998). Emocje - aleksytymia - poznanie. Poznań: Wydawnictwo Humaniora.

Mikołajczuk, A. (1994). Objawy emocji gniewu utrwalone w polskich metaforach potocznych. Poradnik Językowy, (7), 20-29.

Mikołajczuk, A. (1999). Gniew we współczesnym języku polskim. Analiza semantyczna. Warszawa: Wydawnictwo Energeia.

Mikołajczuk, A. (2009). Obraz radości we współczesnej polszczyźnie. Warszawa: Wydawnictwo Semper. 
Mudyń, K. (1991). O przezwyciężaniu społecznych ograniczeń poznania inspirowanych językiem za pomocą operacji dokonywanych na języku. W: A. Tokarz (red.), Stymulatory i inhibitory aktywności twórczej (s. 20-32). Kraków: SAWW.

Nęcka, E. (1992). Trening twórczość. Olsztyn: Polskie Towarzystwo Psychologiczne.

Nęcka, E. (1994). TRoP... Twórcze rozwiązywanie problemów. Kraków: Oficyna Wydawnicza „Impuls”.

Nęcka, E. (2001). Psychologia twórczości. Gdańsk: GWP.

Nęcka, E., Orzechowski, J., Szymura, B. (2006). Psychologia poznawcza. Warszawa: Academica.

Nowakowska-Kempna, I. (2000a). Język ciała czy ciało w umyśle, czyli o metaforyce uczuć. Język a Kultura, (14), 25-58.

Nowakowska-Kempna, I. (2000b). Konceptualizacja uczuć w języku polskim (Cz. 2: Data). Warszawa: Wydawnictwo Wyższej Szkoły Pedagogicznej.

Obuchowski, K. (2004). Kody umysłu i emocje. Łódź: Wyższa Szkoła Humanistyczno-Ekonomiczna.

Ogarkova, A. (2007). "Green-Eyed Monsters": a Corpus-Based Study of Metaphoric Conceptualizations of JEALOUSY and ENVY in Modern English. Metaphoric, (13), 87-147.

Olekszyk, J. (2007). Sposoby wyznawania miłości i mówienia o miłości (na materiale strony internetowej www.wyznania.net). Poradnik Językowy, (7), 55-65.

Pajęcka, J. (2017). Preferowanie określonych metafor miłości w kontekście twórczości emocjonalnej przy kontroli dominującego afektu. Niepublikowana praca magisterska. Poznań: Instytut Psychologii UAM.

Połowniak-Wawrzonek, D. (2007). Metaforyka militarna w określaniu pojęć miłość i zaloty. Poradnik Językowy, (3), 46-56.

Reber, A.S. (2000). Stownik psychologiczny. Warszawa: Wydawnictwo Naukowe Scholar.

Riegel, M., Wierzba, M., Wypych, M., Żurawski, Ł., Jednoróg, K., Grabowska, A., Marchewka, A. (2015). Nencki Affective Word List (NAWL): The cultural adaptation of the Berlin Affective Word List - Reloaded (BAWL-R). Behavior Research Methods, 47(4), 1222-1236. DOI: https://doi.org/10.3758/s13428-014-0552-1.

Saarni, C. (1999). The Development of Emotional Competence. New York: The Guilford Press.

Salovey, P., Detweiler-Bedell, B.T., Detweiler-Bedell, J.B., Mayer, J.D. (2008). Emotional Intelligence. W: M. Lewis, J.M. Haviland-Jones, L.F. Barrett (eds.), The Handbook of Emotions (s. 533-547). New York: The Guilford Press.

Sierotwiński, S. (1985). Stownik terminów literackich. Wrocław: Ossolineum.

Skrodzka, K. (2017). Kreatywność emocjonalna a szybkość rozwiązywania anagramów. Niepublikowana praca magisterska. Poznań: Instytut Psychologii UAM.

Skubalanka, T. (2007). Jeszcze o słownictwie miłosnym języka polskiego. Poradnik Językowy, (9), 3-12.

Soroko, E. (2006). Dlaczego metafora działa? Pytanie o skuteczność terapeutyczną w świetle wiedzy o metaforze. Czasopismo Gestalt, (2), 41-60.

Sternberg, R.J. (2001). Miłość jest opowieścią. Poznań: Rebis.

Sternberg, R.J., Weis, K. (red.). (2007). Nowa psychologia miłości. Taszów: Biblioteka Moderatora.

Trzebińska, E. (2008). Psychologia pozytywna. Warszawa: Wydawnictwa Akademickie i Profesjonalne. 
Trzebiński, J. (1981). Twórczość a struktura pojęć. Warszawa: PWN.

Udzik, J. (2017). Inteligencja emocjonalna i twórczość emocjonalna u kobiet w okresie późnej dorosłości uczęszczających na zajęcia na Uniwersytecie Trzeciego Wieku. Niepublikowana praca magisterska. Poznań: Instytut Psychologii UAM.

Watson, D., Clark, L.A., Tellegen, A. (1988). Development and validation of brief measures of positive and negative affect: The PANAS scales. Journal of Personality and Social Psychology, 54(6), 1063-1070. DOI: https://doi.org/10.1037/0022-3514.54.6.1063.

White, G.M. (2005). Reprezentacje znaczenia emocjonalnego: kategoria, metafora, schemat, dyskurs. W: M. Lewis, J.M. Haviland-Jones (red.), Psychologia emocji (s. 53-71). Gdańsk: GWP.

Wierzbicka, A. (1971). Porównanie - gradacja - metafora. Pamiętnik Literacki, (62), 127-147.

Wiśniewska, D. (2017). Związek stresu mniejszościowego i twórczości emocjonalnej u osób LGB. Niepublikowana praca magisterska. Poznań: Instytut Psychologii UAM.

Wiśniewska-Kin, M. (2009). Miłość jest jak wiatrak, czyli o poznawczej naturze metafor dziecięcych. Łódź: Wydawnictwo UŁ.

Wojciszke, B. (2003). Psychologia miłości. Namiętność, intymność, zaangażowanie. Gdańsk: GWP.

\section{SUMMARY}

Love is a complex emotion. On the one hand, it is a positive experience. On the other, its conceptualization has negative elements. One of the forms of the lexical understanding of emotions is the metaphorical model that makes it possible to reach beyond the literal meaning of emotions. The study with women $(\mathrm{N}=43)$ was conducted. For establishing the lay understanding of love the two types of metaphors were used: typical ones (the target and source domain had the same valence) and atypical ones (the target and source domain had opposite valence). The state affect and emotional creativity were also measured. The obtained data showed that typical metaphors are more preferred, independently of the affect. The metaphor love is a journey enjoyed the most acceptance. The acceptance of atypical metaphors is related to emotional creativity, especially in the field of emotional novelty. The results were discussed in the context of the emotional creators' ability to nonconventional understanding emotional experience. Literature indicates that the understanding of "love as a journey" has a negative emotive expression. This may confirm the tendency to include personal emotional experiences in the scope of the concept of love.

Keywords: love; metaphor; emotional creativity; women 